\section{Violência discursiva, argumentação e memória no cenário político brasileiro: a (des)virtuosidade do discurso público*}

Discursive violence, argumentation and memory in the Brazilian political scenario: the (dis) virtuosity of public discourse

Rodrigo SEIXAS (UFMG) rodrigoseixaspb@gmail.com

Recebido em: 15 de out. de 2018. Aceito em: 27 de fev. de 2019.

*O presente trabalho foi realizado com apoio da Coordenação de Aperfeiçoamento de Pessoal de Nível Superior - Brasil (CAPES) - Código de Financiamento 001.
SEIXAS, Rodrigo. Violência discursiva, argumentação e memória no cenário político brasileiro: a (des)virtuosidade do discurso público. Entrepalavras, Fortaleza, v. 9, n. 1, p. 190-208, janabr/2019.

Resumo: Além dos tão corriqueiros insultos, calúnias e difamações, comuns no período eleitoral, temos acompanhado o aumento de casos de violência explícita, pelo/do discurso, que tendem a fomentar ações e reações reais de violência física pela população. Pode-se dizer que um dos motivos para esse crescimento é o poder persuasivo do discurso e a falta de comprometimento ético por parte dos sujeitos em geral, mas em especial dos agentes políticos, em ajustar seus discursos pelo parâmetro ético da democracia. Nesse sentido, este artigo pretende problematizar os limites éticos do discurso público, lançando luzes sobre a importância de analisar não só o ato discursivo em si, isolado, mas também o agente do ato (PERELMAN; OLBRECHTSTYTECA, 2005), em busca de uma mais bem adequada atividade hermenêutica. Para tanto, analiso o enunciado "vamos fuzilar a petralhada..." por meio da noção de virtude discursiva, proposta por MarieAnne Paveau (2015) e, ao final, aponto para a necessidade de compreensão da responsabilidade (BAKHTIN, 1993) de cada agente como condição para o exercício ético e democrático da palavra pública no Brasil.

Palavras-chave: Violência discursiva. Virtude discursiva. Discurso político. 
Abstract: In addition to the common insults, slander and defamation, common in the electoral period, we have accompanied the increase in cases of explicit violence by discourse that tend to foster real actions and reactions of physical violence by the population. It can be said that one of the reasons for this growth is the persuasive power of discourse and the lack of ethical commitment on the part of the subjects in general, but especially of the political agents, in adjusting their discourses by the ethical parameter of democracy. In this sense, this article intends to problematize the ethical limits of public discourse, shedding light on the importance of analyzing not only the discursive act itself, but also the agent of the act (PERALMAN; OLBRECHTSTYTECA, 2005), in search of a more well-suited hermeneutic activity. To that end, I analyze the statement "vamos fuzilar a petralhada..." through the notion of discursive virtue proposed by Marie-Anne Paveau (2015) and, in the end, point to the need to understand the responsibility (BAKHTIN, 1993) of each agent as a condition for the ethical and democratic exercise of the public word in Brazil.

Keywords: Discursive violence. Discursive virtue. Political discourse.

\section{Introdução}

É sensível à maior parte dos brasileiros que a discussão política no Brasil atingiu níveis perigosos de intolerância e violência neste ano de 2018. Desde 2014, o país vive uma escalada da polarização, já possível de ser vista pela vitória tímida (com pouco mais de 3 milhões de votos) da presidente Dilma Rousseff, pelo Partido dos Trabalhadores (PT), sobre o candidato Aécio Neves, do Partido da Social Democracia Brasileira (PSDB). De lá para cá, outros acontecimentos aumentaram ainda mais a cisão política, como o impeachment de Dilma Rousseff, as ações da Operação Lava Jato e, neste ano, as atuais eleições.

As paixões exacerbadas, produtos da polarização, costumam desencadear ações violentas, como tiros deflagrados contra o ônibus da comitiva de um ex-presidente e, de igual maneira, o golpe de faca sofrido por um candidato. O discurso violento começa a sair do eixo verbal do discurso em si e invade o terreno da ação; passa do ad hominem verbal, discursivo, ao ad hominem literal, físico. Nesse caso, um paradoxo se institui, porque o discurso, em que predomine o teor argumentativo, tem o poder de "modificar um estado de coisas preexistente" (PERELMAN; OLBRECHTS-TYTECA, 2005, p.61), inclusive incitando atos de violência. No entanto, é também defendido pelos autores do Tratado que "o recurso à argumentação supõe o estabelecimento de uma comunidade dos espíritos que, enquanto dura, exclui o uso da violência" (PERELMAN; OLBRECHTS-TYTECA, 2005, p.61) e, portanto, na medida em que se entra no terreno da violência, não se estaria mais no da argumentação, condição basilar da discussão política. 
v. 9 (1)

190-208

jan-abr

2019

Com efeito, a intenção argumentativa é característica de base do discurso político, não apenas em sua função original deliberativa, tal como o tipificou Aristóteles, mas também em sua função educacional (a função epidítica do discurso político), na medida em que serve, igualmente, para educar as pessoas a crerem em determinadas teses, em detrimento de outras; a crerem em determinados projetos de poder; a verem o mundo social através de determinadas lentes.

Podemos dizer, portanto, que a função "argumentativa" do discurso político (apenas como ênfase, posto que não se pode dizer de alguma função não-argumentativa do discurso) é responsável por formar uma comunidade moral entre os participantes de um determinado evento discursivo-político. Nesse sentido, afirmam Perelman e Olbrechts-Tyteca (2005, p. 61),

na medida em que os dirigentes do grupo buscam aumentar sua ascendência sobre o pensamento de seus membros, multiplicarão as reuniões de caráter educativo e alguns chegarão mesmo, no limite, a empregar ameaça ou a coerção para levar os recalcitrantes a se submeterem aos discursos que os impregnarão de valores comunitários.

O tema proposto por esta revista, "A argumentação nas práticas sociais", no atual momento em que vivemos, prevê também a possibilidade de problematizar a qualidade dos discursos em meio a práticas sociais cada vez mais intolerantes. De fato, é possível, por meio dos discursos, perceber certas "virtudes" como marcas indeléveis do engajamento discursivo. Dito isso, e entendendo que os agentes políticos possuem capacidade, pela persuasão, de compartilhar valores morais "desvirtuosos" que podem servir de incentivo a ações igualmente "desvirtuosas", pretendo problematizar a questão da virtude discursiva própria ao discurso político, analisando um caso em que identifico haver ocorrência de um ato flagrante de violência discursiva, a saber, a ocasião em que Jair Bolsonaro afirma, em momento de campanha, que vai "fuzilar a petralhada".

Diante desse discurso, impera o questionamento sobre a adequação do discurso público ao ordenamento democrático. Haveria a possibilidade de uma regulamentação discursiva, ou seria esse um ato flagrante de censura, em nome do estabelecimento do "politicamente correto"? Para fugir de ambos os extremos, creio ser possível discutir uma responsabilidade no discurso, de modo que os atos discursivos, na medida em que são atos éticos, respeitem o ambiente ético próprio ao regime político que configura a ordem pública em nossa sociedade, a saber, a democracia. 
O artigo prescinde, em termos linguísticos, de quadro analítico preciso, uma vez que se trata de problema discursivo mais geral, sem grande incidência na língua em si mesma, mas com profunda implicação no sentido discursivo e na configuração ética dos enunciados. Por assim dizer, preferiu-se contemplar a análise de aspectos semântico-discursivos, retóricos e simbólicos, portanto, reivindicando os sentidos memoriais imediatos de cada enunciado, frente a implicações éticas a eles subjacentes.

\section{A violência no, pelo e do discurso: questões pragmáticas, retóricas e simbólicas}

"A violência não é um valor semântico dos textos, da materialidade das formas verbais, mas uma dimensão pragmática da interação verbal, da colocação dos textos em discurso", assim afirma Rodrigues (2003, p. 13). De fato, não se pode conceber a existência peremptória da violência no nível textual, posto que o fator que define a qualidade violenta de um enunciado apenas pode ser observado no discurso. É, por exemplo, o que se pode perceber nas diferentes situações abstratas: Situação 1 - Em razão de seu aniversário, João, ao ser surpreendido por diversos amigos escondidos em sua casa, diz: "Que susto, vou bater em vocês!". É óbvio que, munidos das informações contextuais, podemos considerar que a afirmação violenta de João se trata, na verdade, de uma brincadeira. Portanto, a análise tão somente semântica, em nível textual, não nos permite chegar a tal conclusão.

O mesmo enunciado pode gerar efeitos discursivos e retóricos bastantes distintos numa hipotética Situação 2 - No seu depoimento à polícia, Henrique relatou: "estávamos eu e mais dois amigos, quando um homem encapuzado, e com um porrete na mão, vociferou: 'nem corram, eu vou bater em vocês'". Ora, neste segundo caso, há outra compreensão do enunciado eu vou bater em vocês, na medida em que se trata de uma afirmação contextualmente indicadora de uma real violência iminente.

Podemos considerar, portanto, que a violência no discurso é dependente das implicações pragmáticas e contextuais. No entanto, a violência pelo discurso, por sua vez, que implica diretamente em uma violência do discurso, apresenta nível um tanto distinto de abordagem. Dizer que existe um ato violento pelo discurso significa pressupor que há, de antemão, um posicionamento negativamente valorativo em relação à este ato. Um ato violento pelo discurso seria, nesse sentido, um ato pragmaticamente estruturado e não ocorreria em quaisquer situações enunciativas ${ }^{1}$.

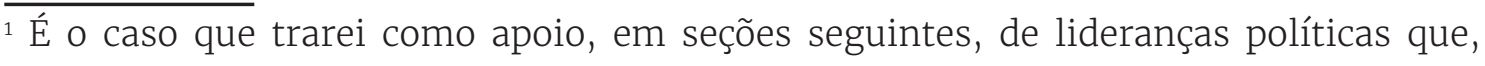


V. 9 (1)

190-208

jan-abr

2019

Um enunciado como "vamos fuzilar a petralhada", excerto do discurso que irei analisar adiante, não afirma nada, em termos semânticos, sobre o estatuto real de violência de tal enunciado (podendo até o político se escusar do ato afirmando se tratar de uma "piada"). No entanto, respeitante a uma fala pública, em termos de recepção, a qual não possui o orador controle de seus efeitos, poder-se-ia mesmo falar de compreensões literais do enunciado. Ademais, é importante ressaltar, por exemplo, que, tendo o vídeo (em que o candidato verbaliza esse enunciado) viralizado nas redes sociais e na internet, haveria um problema quanto à migração do contexto de produção do discurso para outro contexto de recepção totalmente distinto ou, no mínimo, heterogêneo. Esse enunciado, sem dúvidas, pode soar diferente em outro ambiente, de maneira que não há como negar, portanto, os potenciais de violência que cada discurso tem em função de alguns fatores atrelados.

É possível afirmar que há uma dimensão simbólica da violência discursiva que supera questões semânticas e pragmáticas, na medida em que um discurso pode ele mesmo ser considerado como violento, tendo em vista as regras éticas que regulam o corpo social. O perigo da violência do discurso ocorre, como vimos, em larga medida, pelo seu caráter retórico, isto é, pelo potencial que tem em levar as pessoas à ação ou - como afirmam Perelman e Olbrechts-Tyteca (2005) - a uma disposição de ação. De fato, Arendt afirma que

\begin{abstract}
desacompanhada do discurso, a ação perderia não só o seu caráter revelador como, e pelo mesmo motivo, o seu sujeito, por assim dizer: em lugar de homens que agem teríamos robôs mecânicos a realizar coisas que seriam humanamente incompreensíveis. Sem o discurso, a ação deixaria de ser ação, pois não haveria ator; e o ator, o agente do ato, só é possível se for, ao mesmo tempo, o autor das palavras. A ação que ele inicia é humanamente revelada através de palavras; e, embora o ato possa ser percebido em sua manifestação física bruta, sem acompanhamento verbal, só se torna relevante através da palavra falada na qual o autor se identifica, anuncia o que fez, faz e pretende fazer (ARENDT, 2007, p. 191).
\end{abstract}

Nesse sentido, é temerário desconsiderar o poder que um discurso violento tem em fomentar movimentos e ações. Não se pode esquecer, por exemplo, ter sido essa a desculpa dada por Adélio (e neste ponto não se pretende de forma alguma respaldar o ato) como motivo para a tentativa de assassinato do candidato Jair Bolsonaro, porquanto

mesmo cientes de suas funções e importância no cenário político nacional, produzem enunciados no mínimo imprudentes, incoerentes ao decoro próprio à atividade pública. 
se sentia ameaçado por suas ideias e palavras. A violência do discurso, nesse sentido, é uma forma de violência simbólica, pois incute valores próprios a uma ética incompatível com os princípios democráticos de respeito à existência no mundo dos sujeitos que encarnem valores divergentes.

É indiscutível, não obstante, que há necessidade de diferenciação dos níveis de violência, de modo que insultar alguém (chamar de "corrupto", por exemplo) certamente não tem o mesmo peso simbólico que enunciar "vamos fuzilar a petralhada". Quanto a isso, parece-me consensual dizer: a violência discursiva é uma violência simbólica, na medida em que trata de impor aos sujeitos formas de ver e de pensar a realidade condizente a uma perspectiva violenta desde a gênese do discurso em questão, e, nesse sentido, é preciso compreender o status dessa violência discursiva para além de implicações tão somente semânticas ou pragmáticas.

\section{Violências discursivas no cenário político brasileiro: os atos e os agentes dos atos}

Não faltam exemplos para ilustrar casos de violência discursiva que, se considerados como atos normais da atividade política, tendem a institucionalizar o caos. Há, no entanto, um candidato ${ }^{2}$ campeão de polêmicas como essas, a saber, Jair Bolsonaro, do Partido Social Liberal (PSL), como é possível verificar na matéria publicada pela jornalista Juliana Cipriani, na seção Política do Estado de Minas³, do dia 14 de abril de 2018.

Posicionar-se polemicamente sobre assuntos sensíveis à discussão social, porquanto prática recorrente, acaba por contribuir, sem dúvidas, à sedimentação do ethos de violento, autoritário e intolerante de Bolsonaro. Por assim dizer, o ethos, se entendido pela ótica dos autores do Tratado da argumentação, não se reduz a uma construção de imagem do orador no momento de sua fala, mas se atrela, antes, a uma continuidade de agência - leia-se atos de uma pessoa -, no decorrer das enunciações produzidas por um sujeito. Isso é próprio, para eles,

\footnotetext{
${ }^{2}$ É necessário salientar que este artigo foi escrito em pleno período eleitoral, de maneira que o tratamento aos agentes políticos em questão como candidatos é adequado.

${ }^{3}$ CIPRIANI, Juliana. Veja 10 frases polêmicas de Bolsonaro que o deputado 'considerou' brincadeira. Seção Política. Estado de Minas (EM). Disponível em:<<https://www. em.com.br/app/noticia/politica/2018/04/14/interna_politica, 951685/10-frasespolemicas-de-bolsonaro-que-o-deputado-considerou-brincadeira.shtml >>. Acesso em 27 de Set. 2018.
} 
V. 9 (1) 190-208 jan-abr 2019

da construção da pessoa humana, a qual "se vincula aos atos, é ligada a uma distinção entre o que se considera importante, natural, próprio do ser de quem se fala, e o que considera transitório, manifestação exterior do sujeito" (PERELMAN; OLBRECHTS-TYTECA, 2005, p. 334). Ainda segundo os autores,

como essa ligação entre a pessoa e seus atos não constitui uma relação necessária, como não possui características de estabilidade da relação existente entre um objeto e suas qualidades, a simples repetição de um ato pode acarretar, seja uma reconstrução da pessoa, seja uma adesão fortalecida à construção anterior (PERELMAN; OLBRECHTS-TYTECA, 2005, p. 334).

A negação de necessidade apontada pelos autores a propósito da relação entre pessoa e ato não significa dizer que a pessoa é, então, totalmente livre dos predicados que seus atos possam vir a qualificar. O que ocorre, na verdade, é a negação de uma relação completamente objetiva, determinista, que implique uma pessoa necessariamente inclinada a produzir um ato. Uma mesma pessoa pode produzir atos moralmente opostos, por exemplo, e continuar sendo a mesma pessoa, com os mesmos predicados. É por isso que se pode compreender o ato, de certa maneira, como um ato livre (ainda que sofra coerções simbólicas de todo tipo) e que a pessoa tende a ser um saldo de todos os seus atos, repetidos na esteira do tempo. Tal configuração leva Perelman e Olbrechts-Tyteca a considerarem que é impossível analisar um ato, implicando-lhe um valor e constituindo sentidos a partir dele, sem que haja uma análise, em conjunto, da pessoa do ato. Isso porque,

na argumentação, a pessoa, considerada suporte de uma série de qualidades, autora de uma série de atos e de juízos, objeto de uma série de apreciações, é um ser duradouro a cuja volta se agrupa toda uma série de fenômenos aos quais ele dá coesão e significado" (PERELMAN; OLBRECHTS-TYTECA, 2005, p. 336).

Importante frisar, no entanto, que a coesão e o significado dados pela pessoa ao conjunto de seus atos não podem corresponder à totalidade de sentido na apreensão destes, na medida em que o valor do ato depende diretamente dos valores do auditório e não apenas do orador. Um mesmo discurso, sabidamente violento por diversas pessoas, pode ser compreendido, por outras, apenas como uma "piada", "brincadeira", ou como "figura de linguagem".

Independentemente do valor axiológico dado ao ato, o seu valor fenomênico, ou seja, pela sua própria existência no mundo, para 
além de um indício, é também "um elemento que permite construir e reconstruir nossa imagem da pessoa, classificar esta em categorias às quais se aplicam certas qualificações" (PERELMAN; OLBRECHTSTYTECA, 2005, p. 338). Com efeito, os atos contínuos de uma pessoa têm o poder de reconstruir a imagem positivamente ou, na mesma capacidade, também o têm de destruí-la e, ainda, de sedimentar imagens antes instituídas. Neste ponto, é imediata a relação entre o ato e o ethos, quer seja pela noção clássica grega como "caráter", e sua contribuição à noção posterior de ética, como também pela noção clássica latina virtus, traduzida posteriormente como virtude. Segundo Sobral (2009), com efeito, o ato é sempre, em termos bakhtinianos, um ato ético, em que pese à inscrição e à responsabilidade do agente em cada ato, e todo ato ético submete-se ao crivo de uma determinada virtude, ou a um conjunto de virtudes, que lastram e positivam o que se considera moral a cada época, lugar social, profissão etc.

Não há como negar, portanto, que a dimensão moral (ou ética ${ }^{4}$ ) do ato discursivo é algo inerente à constituição do discurso. Não há discurso "asséptico", não há discurso ausente de marcas axiológicas e, portanto, sem juízos de valor acerca de determinados fenômenos, pessoas, fatos ou objetos do mundo. Segundo Pires e Sobral (2013, p. 217), apoiados na concepção bakhtiniana, "dizer é dizer-se". Em outras palavras, o ato de linguagem é sempre um ato ontológico, pois é o ato do ser e, consequentemente, um ato axiológico, porquanto o ser humano não se desvencilha dos valores e das crenças a que subjazem as suas enunciações.

Nessa mesma perspectiva, Benveniste (apud PAVEAU, 2015, p. 34), num trecho que, segundo Marie-Anne Paveau, é pouco citado, afirma que "muito antes de servir para comunicar, a linguagem serve para viver". A linguista afirma que, para além do discurso ou dos efeitos de discurso, a concepção de moral deve observar o "homem que fala" (PAVEAU, 2015, loc. cit.). Posto que "a faculdade de linguagem é, de fato, uma faculdade do ser e até mesmo sua condição de existência" (PAVEAU, 2015, loc. cit.), torna-se possível, por meio da linguagem, perceber os seus indicadores éticos e, por corolário, reconhecer a existência de virtudes discursivas nas relações intersubjetivas, que podem servir como norte para todo e qualquer tipo de ato argumentativo.

\footnotetext{
${ }_{4}^{4}$ Marie-Anne Paveau (2015) dedica uma seção de seu livro apenas para falar sobre as distinções entre ética e moral. Assim como ela, não as tomo aqui como sinônimas. No entanto, tratarei, semelhantemente à autora, da concepção de "moral" para designar a dimensão valorativa própria aos agentes, possível de ser depreendida em seus atos discursivos.
} 
V. 9 (1)

$190-208$

jan-abr

2019

\section{A dimensão ética e moral das virtudes discursivas}

A linguista Marie-Anne Paveau, em seu livro Linguagem e moral, problematiza, a partir da noção de virtude discursiva, a dimensão ética e moral dos usos de linguagem, a qual ainda é pouco trabalhada na Linguística por razão de uma pretensão objetivista e descritiva por parte de seus teóricos. Segundo sua hipótese, "no conjunto dos usuários de uma língua tomada nos contextos culturais, históricos e sociais, realmente existem critérios morais para a produção discursiva" (PAVEAU, 2015, p. 24). A noção de virtude discursiva está atrelada a alguns ajustes:

ajuste dos discursos ao mundo, traduzido pela ideia de "verdade" das palavras [...]; ajuste dos discursos às memórias discursivas que os informam e possibilitam [...]; ajustes dos discursos às normas de relação com os agentes, admitidas numa sociedade. O conjunto desses elementos constitui aquilo que chamo de virtude discursiva, que funciona no âmago de uma ética dos valores [...] e supõe uma negociação intersubjetiva no interior de dado grupo ou dada sociedade (PAVEAU, 2015, p. 26).

É possível compreender, por conseguinte, que a virtude discursiva é um conjunto complexo de implicações da dimensão moral dos enunciados. Para Paveau (2015), tal dimensão "emerge de um 'acontecimento discursivo moral', ou seja, de um conjunto de comentários e reações, em dado grupo ou sociedade, a propósito de dado enunciado" (PAVEAU, 2015, loc. cit.). Por assim dizer, um ato de violência discursiva tende a ocasionar uma série de reações, negativas e em repúdio, em sua maioria, mas também as que lhe são favoráveis. Tal concepção se alinha ao que dizem os autores do Tratado: "o valor que atribuímos ao ato nos incita a atribuir um certo valor à pessoa" (PERELMAN; OLBRECHTSTYTECA, 2005, p. 339). Decerto, se considerarmos que a orientação sexual se resolve com "cura gay" ou com "pauladas" (expressões presentes no discurso da homossexualidade que a veem como uma doença ou como algo criminoso), logo valorarei, de forma positiva, o posicionamento de um sujeito que se alinhe a esse pensamento. O movimento contrário é de igual validade: na medida em que me identifico com a pessoa de certo candidato ou político, tenderei a me identificar com seus valores e, por consequência, com seu discurso.

No entanto, Paveau (2015), apesar de concordar com a condicionalidade de identificação valorativa, considera que há na linguagem uma dimensão moral propriamente dita que não é 
forçadamente dependente dos condicionantes axiológicos. Isto é, haveria um "padrão" (que não é imutável, por certo) em uma determinada sociedade, em determinado momento da história, para determinada classe ou profissão, em considerar algo como moral ou imoral, como ético ou antiético. Sendo assim, por analogia sintética, haveria igualmente um padrão no que se refere à consideração de algo como violento ou não, que vai além das implicações semânticas ou de contexto imediato, transcendendo, tais aspectos, ao pôr em cena questões mais amplas, respeitantes à memória discursiva, às configurações socioinstitucionais - as quais Paveau (2015) chama de ambiente - e aos pré-discursos em atividade. Segundo ela, o "discurso virtuoso" pode ser definido como "o discurso ajustado aos valores vigentes na realidade complexa e instável dos agentes e de seus ambientes" (PAVEAU, 2015, p. 214). A linguista afirma que tal ajuste diz respeito a três elementos, a saber:

Os agentes e suas relações (o que pode ser descrito por meio da noção de decência, extraída de A. Margalit), o mundo (a realidade e suas representações) e o conjunto das produções verbais que constituem a memória discursiva das sociedades (discurso, pré-discursos, linhagens discursivas). Esses elementos formam um sistema ao mesmo tempo discursivo, cognitivo e ético, no qual estão profundamente imbricados (PAVEAU, 2015, p. 214).

Como afirmado acima, o sistema possui um 1 - eixo ético, que diz respeito ao agente e suas relações. Ora, como vimos anteriormente, é próprio do orador - o qual Paveau (2015) chama de agente-falante a construção de uma imagem credível de si, mas é também necessário levar em conta as imagens do auditório, em função do qual se constrói uma argumentação. Ao mesmo tempo, aparece o 2 - eixo cognitivo, vez que se pode aventar uma partilha (ou apropriação, no limite) de formas de ver o mundo entre o orador e o auditório (ou o agente-falante e o agente-ouvinte). É também de ordem cognitiva as representações que se fazem do mundo em determinada época, de modo que não há quase nunca, para o mesmo fenômeno, a mesma percepção e concepção, em diferentes épocas ou lugares. Há, por último, 3 - o eixo discursivo, em que pese ser sempre por meio do discurso que se torna possível a produção e compreensão de sentidos. Neste eixo está inserido todo o desdobramento do discurso, como os pré-discursos, a memória discursiva, a linhagem discursiva etc.

A partir do desdobramento desses três elementos (ou eixos) expostos por Paveau (2015), é possível problematizar a violência no/ 
V. 9 (1)

190-208

jan-abr

2019

pelo/do discurso, utilizando, para tanto, um enunciado proferido pelo candidato Jair Bolsonaro, em momento de campanha à Presidência do Brasil. Seria um discurso violento possível de ser virtuoso, ou seria a suposta desvirtuosidade de tais discursos razão suficiente para que se defenda uma ética do discurso político, da argumentação política, observável por todos os seus agentes? Discutirei essa questão a partir do enunciado-base "fuzilar a petralhada...".

\section{"Fuzilar a petralhada"}

O candidato do PSL, em visita política ao Estado do Acre, proferiu as seguintes palavras: "Vamos fuzilar a petralhada aqui do Acre, hein? Vamos botar esses picaretas para correr do Acre. Já que eles gostam tanto da Venezuela, essa turma tem de ir pra lá. Só que lá não tem nem mortadela, hein, galera?! Vão ter de comer é capim mesmo!" (Jair Bolsonaro, em campanha no Acre, no dia 03 de Setembro de 20185).

Diante deste enunciado, algumas implicações se mostram necessárias à análise. A primeira delas [1] diz respeito às implicações políticas possíveis de serem depreendidas pelas escolhas lexicais do candidato, as quais apontam, irrenunciavelmente, a um estado flagrante de guerra. Ora, não foi a primeira nem será a última comparação que se faz da política enquanto um lugar de batalhas. De fato, Weber (2004) considera que a política é da ordem da dominação, uma incessante disputa pelo poder. Segundo Bobbio, é possível compreender a relação de poder de distintas maneiras, dentre as quais se "reconhecem fórmulas típicas da linguagem política: como relação entre governantes e governados, entre soberano e súditos, entre Estado e cidadãos, entre autoridade e obediência, etc." (BOBBIO, 1998, p. 955). Resta dizer, sem dúvidas, que os agentes de poder político, diante de um conflito e no intuito de garantir a conquista ou manutenção da dominação, da governança, ou mesmo da ingerência em assuntos de seu interesse, pode-se valer de instrumentos de dominação próprios à guerra, que se mascaram em linguagem política.

Mouffe(2005), entretanto, considera queo conflitoé compreendido de diferentes maneiras, em função da distinção entre o político e a política. Segundo a politóloga, o político é a instância conflitiva por essência e a política

\footnotetext{
${ }^{5}$ RIBEIRO, Janaína. "Vamos fuzilar a petralhada", diz Bolsonaro em campanha no Acre. Seção Brasil. Exame. 4. Set. 2018. Disponível em: <<https://exame.abril.com. br/brasil/vamos-fuzilar-a-petralhada-diz-bolsonaro-em-campanha-no-acre/>>. Acesso em: 30 Set. 2018.
} 
a sua instância reguladora, por meio do conjunto de práticas (inclusas as normas éticas), discursos e instituições. Assim, consegue-se discernir o conflito que é próprio da guerra e o que o é da política, pela distinção entre as categorias de inimigos e adversários. Para Mouffe,

o propósito da política democrática é construir o 'eles' de tal modo que não sejam percebidos como inimigos a serem destruídos, mas como adversários, ou seja, pessoas cujas ideias são combatidas, mas cujo direito de defender tais ideias não é colocado em questão (MOUFFE, 2005, p. 20).

Neste sentido, é preciso haver um mesmo código ético mínimo, próprio ao sistema democrático, que forneça, parafraseando Angenot (2008), um código retórico possível e por meio do qual a discussão pacífica se torne também possível. Do contrário, há a tendência de se chegar a um irremediável diálogo de surdos, na melhor das hipóteses, porque se pode mesmo aventar uma total falta de diálogo em situações de completa anarquia ética.

O uso do verbo "fuzilar", destarte, evoca uma relação entre inimigos e não entre adversários no jogo democrático. Não é necessário mencionar distintas definições do verbo para ter em mente que não se trata de um termo de carga semântica leve. "Fuzilar" é muito mais que tão simplesmente "matar" a tiros, porque traz consigo a ideia da indisponibilidade, por parte do fuzilado, do direito a defender-se. Esse tipo de prática ainda existe em alguns países como pena de morte por delitos graves, como também é prática comum de facções no extermínio de membros de facções rivais. De todo modo, em nenhum caso, é o ato de fuzilar alguém algo aceitável numa democracia plena. Não é, tampouco, aceitável a incitação ao crime por meio do discurso, como tipificado pelo Art. 286, do Código Penal Brasileiro (BRASIL, 1940).

No entanto, para além da semântica, é necessário revisitar a [2] memória discursiva em ação - a segunda implicação necessária à análise - que é automaticamente evocada quando há um enunciado como esse, vindo de um capitão reformado do Exército Brasileiro. Sabe-se que, durante 21 anos de sua história, o Brasil viveu uma ditadura militar com forte ímpeto opressivo aos recalcitrantes. Segundo o historiador Boris Fausto, se a opressão já existia desde o início do regime, a partir do ano de 1968, com a instituição do AI-5, ela tomou rumos ainda mais violentos, tendo na tortura e no extermínio por execução sumária (a maior parte por emboscadas militares, seguidas de fuzilamento) meios comuns para contenção de opositores radicais ao regime (FAUSTO, 2015). 
V. 9 (1)

190-208

jan-abr

2019

O ato de pegar um tripé, manuseá-lo de forma análoga a um rifle, e dizer "vamos fuzilar a petralhada" possui o poder de remeter a uma re-efetuação da memória (RICOEUR, 1994). Com efeito, o processo de mimesis é automático, ao menos para as pessoas que consideram o período do regime militar como uma transgressão à ética dos direitos humanos. A memória discursiva tem, justamente, como uma de suas funções "construir discursos em termos de outros, em complexos jogos de analogias, heranças, reformulação e polissemia" (PAVEAU, 2015, p. 234).

Sendo assim, não há dúvidas da existência de um processo analógico, metafórico em termos amplos, no ato praticado pelo candidato do PSL. Como afirma Paveau (2015), não é possível afirmar uma (des) virtude discursiva sem levar em conta a postura ética do agente-falante, ou, segundo Perelman e Olbrechst-Tyteca (2005), da pessoa responsável pelos atos. É por isso que, ao endossar, em entrevista recente ${ }^{6}$, o papel benéfico da tortura, o candidato Jair Bolsonaro agrega sentido para seu ethos enquanto um defensor de tais tipos de práticas. Portanto, tal enunciado, de um discurso público, não pode ser simplesmente considerado uma mera "figura de linguagem", se levados em conta os critérios de validação ética pertinentes a um Estado Democrático.

O processo de memória não se resume, todavia, ao enunciado "fuzilar a petralhada". Se nos apropriarmos do restante do discurso, podemos perceber que há outro termo em diálogo direto com a memória do regime militar. Trata-se do termo "Venezuela". O regime socialista que governa o país vizinho possui, igualmente, traços extremamente autoritários pelos quais o tal regime é, ao menos por grande parte dos agentes políticos brasileiros, categoricamente classificado como um caso de ruptura da ordem democrática.

Não se pode negar que nenhuma memória discursiva se sustenta de maneira isolada. É sempre um interminável diálogo, nos termos bakhtinianos, a partir do qual se afirma que toda enunciação é uma atualização de sentidos na história dos discursos. Tais atos dialogam, por exemplo, com uma suposta simpatia entre o PT e regime venezuelano, acusada por Bolsonaro e seus seguidores e que é alimentada, segundo eles, pelos repetidos manifestos de apoio que o PT, sobretudo em nome de sua presidente, Gleise Hoffmann, deu/dá ao regime madurense.

${ }^{6}$ OSAKABE, Marcelo. Bolsonaro no Roda Viva: 'Não houve golpe militar em 1964'. Estado de São Paulo. 30 jul. 2018. Disponível em:<<https://politica.estadao.com.br/ noticias/eleicoes, nao-houve-golpe-militar-em-64-afirma-bolsonaro-no-rodaviva,70002423000>>. Acesso em: 31 Set. 2018. 
Ora, segundo Reis (2014), o grande argumento para a instalação de um regime militar no ano de 1964 foi justamente um suposto risco de uma revolução "comunista", que tinha como projeto de poder o pretenso estabelecimento de uma ditadura comunista no Brasil. Contra esses ares revolucionários, os militares assumiram o poder, por meio de um Golpe de Estado.

Afirmar, portanto, na mesma vizinhança de enunciados, que é necessário "fuzilar a petralhada" e "já que eles gostam tanto da Venezuela, essa turma tem de ir pra lá", o resgate possível de ser feito da memória discursiva evidencia, justamente, discursos existentes de uma ideologia civil-militar-conservadora contra os discursos (dito comunistas) de resistência ao regime de 64. Angenot (2008), a esse fenômeno, chama de "arsenais argumentativos", os quais, segundo ele, consistem em uma série de argumentos que voltam sempre no decorrer da história pela atualização de polêmicas já existentes, conferindo sentidos através do tempo por meio da memória discursiva.

A terceira implicação evoca os [3] traços cognitivos e éticos. Entendo como traços cognitivos as marcas de modelos de pensamento possíveis de serem compreendidos no discurso. É o caso, por exemplo, do modelo mental bélico, a partir da metáfora da guerra, comum nos discursos bolsonaristas. É corrente, quanto a isso, os usos dos termos "guerra", "fuzilar", como analisado neste artigo, mas também "dizimar a esquerda" e tantos outros verbos e vocábulos referentes ao mundo da guerra, que constroem, consequentemente, padrões de pensamento por meio dos quais os sujeitos participantes de uma determinada comunidade discursiva passam a apreender a realidade. Tudo isso acontece, segundo Ricoeur (1994), por meio de processos metafóricos, passados adiante de maneira sutil, mas imediata. Ao evocar a memória de luta contra a ameaça comunista, e em fazendo uso de metáforas de uma suposta guerra em curso, é possível haver igualmente uma transferência ética que flexibiliza o uso de violência discursiva e simbólica (no limite, também física) pelo que se pode entender de um estado de exceção discursivo. Ou seja, seria preciso utilizar os meios cabíveis para remediar tamanho mal e que, portanto, a violência seria mesmo justificada.

Parece-me, nesse ponto, existirem ilhas cognitivas que, enquanto "ilhas", estão separadas do continente e abrigam igualmente sujeitos isolados da jurisdição moral própria ao regime democrático. No entanto, a distância, para além de metaforicamente geográfica, é, sobretudo, de ordem psicológica, social e cognitiva. A forma como os 
V. 9 (1)

$190-208$

jan-abr

2019

grupos políticos compreendem a realidade são distintas, como também distintas são as doxai que fundamentam as argumentações de cada indivíduo desses grupos. O que ocorre é que, dentro de uma democracia, mesmo as doxai declaradamente divergentes devem apontar para um mínimo de respeito a princípios democráticos de base. Discursos que atentem a esses princípios não podem ser considerados ajustados ao ambiente democrático, ainda que se ajustem a determinadas doxai de uma sociedade democrática.

É natural, contudo, que distintas percepções éticas sobre a democracia se construam num mesmo ambiente, sobretudo se falarmos de um país de dimensões continentais e diverso como o Brasil. Alguns concebem a democracia como o irrestrito cumprimento da lei e da ordem constitucional (uma concepção tecnicista, poderíamos dizer), enquanto outros consideram que democracia é o respeito às divergências, pela garantia dos direitos humanos, políticos, civis e sociais de cada indivíduo (uma concepção política e humanitária, portanto).

No entanto, ainda que plurais, há margem para considerar que existem princípios básicos de toda e qualquer experiência democrática. Por certo, em um regime democrático, fruto da luta de um povo desde o processo da redemocratização (que já faz 23 anos), os valores éticos a serem observados por lei devem ser os da democracia. A propósito, tais princípios são, há muito tempo, defendidos em distintas sociedades, como se pode ver nos documentos Bills of Rights das colônias americanas, em 1776, e a Déclaration des droits de l'homme et du citoyen, de 1789, na França, os quais figuram os direitos civis, políticos e sociais como garantias do funcionamento democrático.

De igual maneira, a Constituição de 1988, marca da redemocratização brasileira, estabelece algumas cláusulas pétreas, em seu artigo $5^{\circ}$, as quais afirmam, entre outros, os mesmos direitos acima, próprios à garantia da cultura democrática. Nesse sentido, é possível considerar como ambiente virtuoso justamente a cultura e o clima democráticos que a Constituição intentou implementar há 20 anos. Em suma, o discurso público, justamente por ser de todos [res pública], deve se parametrizar por uma ética abrangente e democrática, reguladora do todo, que garanta o respeito às diferentes vozes e modos de existência, ainda que o agente político com eles não concorde. 


\section{A (des)virtuosidade do discurso e a responsabilidade discursiva}

Afirmar a necessidade de ajuste do discurso público a algumas virtudes discursivas não seria uma coerção à liberdade da palavra? É por essa razão que se prefere, falar de responsabilidade e não de regras discursivas, na medida em que, ao falar de regras, foca-se no ato enquanto componente objetivo, mas, ao falar de responsabilidade, implicase necessariamente a pessoa e sua relação ética para com esse ato. A questão da responsabilidade é vista da seguinte forma por Moirand,

Se pensarmos que a linguagem tem uma responsabilidade na construção da realidade social [...], essa ética se manifestaria no modo de nomear (designar, caracterizar) fatos e acontecimentos, atores, suas ações e seus atos de linguagem, bem como a maneira de representar o que eles dizem: uma ética da responsabilidade implica que não se tem o direito de não se interessar pelas consequências dos próprios atos de linguagem, e não deixa de ter consequências, por exemplo, escolher entre jovem e ralé, entre estudante ou anarquista, para designar os atores de um acontecimento ou transmitir sem distância e/ou sem noção (MOIRAND apud PAVEAU, 2015, p. 218).

Bakhtin (1993), de igual maneira, considera que a compreensão de um objeto no mundo passa por

compreender meu dever em relação a ele (a atitude ou posição que devo tomar em relação a ele), isto é, compreendê-lo em relação a mim mesmo [...] e isso pressupõe minha participação responsável, e não uma abstração de mim mesmo (BAKHTIN, 1993, p. 35).

A responsabilidade do eu seria, assim, também uma responsabilidade pelo outro. O dizer no espaço público, no mundo da vida, engaja automaticamente as pessoas umas em relação às outras, de modo que negar a força do ato no que tange ao poder de persuasão, de modificar crenças, valores e de levar as pessoas à ação é negar a própria força do discurso.

Isso não significa, todavia, afirmar uma determinação arbitrária do que se possa dizer no espaço público. Danblon (2004) considera a possibilidade de instituição de quaisquer limites a uma eventual violência pelo discurso um perigo próximo à censura. Ela afirma que:

se a linguagem pode produzir discursos tais como o insulto ou a ameaça, que criam efeitos semelhantes aos da violência física, seria grave e perigoso, de um ponto de vista político tanto quanto psicológico, de confundir estes discursos totalmente com esta violência (DANBLON, 2004, p. 64). 
V. 9 (1)

$190-208$

jan-abr

2019

No entanto, diferentemente da ameaça e do insulto, há casos de violência discursiva que ultrapassam o domínio do que poderia ser considerado apenas como "politicamente correto", na medida em que deixa de ser um problema de polidez linguística e passa a ser uma questão de atentado contra a paz democrática. O que ocorreu no ato analisado, em especial, foi uma não responsabilidade pelo ato, uma "desvirtuosidade discursiva", seja por desconsideração do valor potencial e real de violência que lhe é imputado, seja pela desnaturalização da seriedade do discurso.

\section{Considerações finais}

Pretendeu-se com este trabalho apontar para uma necessidade de reflexão sobre as consequências de um discurso que ultrapasse os limites ético-democráticos do exercício da palavra, uma vez que o agente político não deve considerar o seu antagonista como inimigo, mas sim como adversário. Neste sentido, considero ser possível o estabelecimento de limites aos atos de violência discursiva, não por meio de uma deontologia censurista do discurso, mas sim pela educação virtuosa a fim de estabelecer, a médio e longo prazo, uma cultura democrática que torne inaceitáveis atos como estes. Segundo Paveau (2015), a propósito, é possível falar de uma mudança de postura, da desvirtuosidade de um discurso para a sua virtuosidade, nos termos de uma reeducação axiológica, o que pode mesmo parecer utópico em termos práticos.

Julgo, entretanto, que a retórica possui as características pedagógicas necessárias para o estabelecimento, ao mesmo tempo, da liberdade da palavra e da consciência respeitosa ao divergente, ao menos como a compreendem Perelman e Olbrechts-Tyteca (2005); uma educação retórica para o debate, que leve em conta a adequação do discurso aos princípios ético-democráticos, os quais são, inclusive, o pano de fundo para o surgimento da retórica desde a era clássica.

Em suma, adotar um regime político pressupõe a adoção de um regime jurídico e, em certa medida, de um regime discursivo. Em uma democracia, tais regimes precisam observar princípios pautados pela civilidade, esta que, mais que a simples razão, parece ser (ou ao menos deveria) a condição a nos separar dos animais. 


\section{Referências}

ARENDT, Hannah. A condição humana. Tradução Roberto Raposo. 10 a ed. Rio de Janeiro: Forense Universitária, 2007.

ANGENOT, Marc. Dialogues des sourds: traité de rhétorique antilogique. Paris: Mille et une nuits, 2008.

BAKHTIN, Mikhail. Para uma filosofia do ato (1919-1921). Tradução de Carlos Alberto Faraco e Cristovão Tezza do texto da edição americana Towards a Philosophy of the Act. Austin: University of Texas Press, 1993.

BOBBIO, Norberto. Dicionário de política. Tradução Carmem C, Varriale et ai. Brasília: Editora da UNB, 1998.

BRASIL. Decreto-Lei 2.848, de 07 de dezembro de 1940. Código Penal. Diário Oficial da União, Rio de Janeiro, 31 dez. 1940.

BRASIL. Constituição (1988). Constituição da República Federativa do Brasil. Brasília, DF: Senado Federal: Centro Gráfico, 1988. 292 p.

CIPRIANI, Juliana. Veja 10 frases polêmicas de Bolsonaro que o deputado 'considerou' brincadeira. Seção Política. Estado de Minas (EM). 2018. Disponível em: <https://www.em.com.br/app/noticia/politica/2018/04/14/ interna_politica, 951685/10-frases-polemicas-de-bolsonaro-que-odeputado-considerou-brincadeira.shtml>. Acesso em: 27. Set. 2018.

DANBLON, Emmanuelle. Argumenter en démocratie. Bruxelas: Éditions Labor, 2004.

FAUSTO, Boris. História do Brasil. 14. ed. São Paulo: Editora da USP, 2015.

MOUFFE, Chantal. "Por um modelo agonístico de democracia". Revista Sociologia Política, Curitiba, 25, p. 11-23, nov. 2005.

OSAKABE, Marcelo. Bolsonaro no Roda Viva: 'Não houve golpe militar em 1964'. Estado de São Paulo. 30 jul. 2018. Disponível em:https://politica. estadao.com.br/noticias/eleicoes, nao-houve-golpe-militar-em-64-afirmabolsonaro-no-roda-viva,70002423000. Acesso em: 31.Set. 2018.

PAVEAU, Marie-Anne. Linguagem e moral: uma ética das virtudes discursivas. Tradução Ivone Benedetti. Campinas/SP: Editora da Unicamp, 2015.

PERELMAN, Chaïm; OLBRECHTS-TYTECA, Lucie. Tratado da argumentação: a nova retórica. Tradução Maria E. de Almeida Prado Galvão. São Paulo: Martins Fontes, 2005.

PIRES, Vera Lúcia; SOBRAL, Adail. "Implicações do estatuto ontológico do sujeito na teoria discursiva do Círculo Bakhtin, Medvedev, Voloshínov". Bakhtiniana, São Paulo, 8 (1): pp. 205-219, Jan./Jun., 2013.

REIS, Daniel Aarão. Ditadura e democracia no Brasil. São Paulo: Zahar, 2014 RIBEIRO, Janaína. "Vamos fuzilar a petralhada", diz Bolsonaro em campanha no Acre. Seção Brasil. Exame. 4. Set. 2018. Disponível em: <<https://exame.abril. com.br/brasil/vamos-fuzilar-a-petralhada-diz-bolsonaro-em-campanhano-acre/>>. Acesso em: 30 Set. 2018. 
v. 9 (1) 190-208 jan-abr 2019
RICOEUR, Paul. Tempo e narrativa. Tomo I. São Paulo: Papirus, 1994.

RODRIGUES, Adriano Duarte. "Do discurso da violência à violência do discurso". Revista da Faculdade de Ciências Sociais e Humanas da UNL, n ${ }^{0}$. 16, Lisboa, Edições Colibri, 2003, pp. 13-24.

SOBRAL, Adail. "O conceito de ato ético de Bakhtin e a responsabilidade moral do sujeito". Bioethikos. Centro Universitário São Camilo - 2009; 3(1):121-126.

WEBER, Max. Ciência e política: duas vocações. Tradução Leonidas Hegenberg e Octany Silveira da Mota. São Paulo: Cultrix, 2004. 